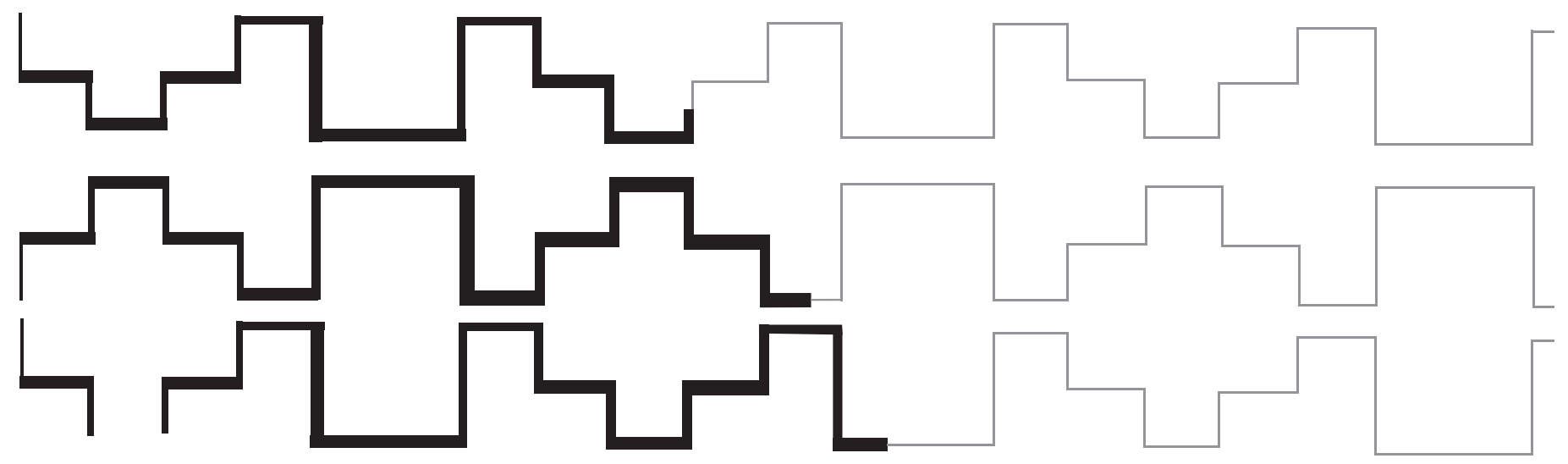

\title{
A cidade moderna: Belo Horizonte nas crônicas de Carlos Drummond de Andrade
}

\author{
Valéria Aparecida de \\ Souza Machado
}

\section{Resumo}

Este artigo propõe uma reflexão sobre as relações entre literatura e sociedade , cujo foco está voltado para as transformações da cidade moderna e ao modo como os processos de modernização interferiram nas relações espaciais e sociais. A diversidade inaugurada pela modernidade fez do espaço citadino um lugar de contradições, paradoxos e ambiguidades, entrevistos nas imagens e signos da cidade. Símbolo da primeira grande obra da República brasileira, Belo Horizonte nasceu como o marco de uma nova mentalidade que veio para sepultar as marcas deixadas pela dominação do Império. A ocupação do espaço urbano se deu de forma hierarquizada e segregativa, representando um modelo urbano que exercia o controle sobre as massas. O objeto de análise do ensaio são as crônicas de Carlos Drummond de Andrade publicadas no jornal Minas Gerais, entre 1930 e1934, que demonstram o modo como o escritor construiu suas representações sobre a da cidade moderna.

Palavras-chave: literatura; cidade; modernidade 


\begin{abstract}
This text deals with the connections between literature and society, mainly the transformations of the modern city and the way the modernizing processes interfere with the space and social relations. The diversity introduced by modernity has transformed the space of cities into a place of contradictions, paradoxes and ambiguities, as can be seen in urban images and signs. Built as an emblem of the first great work of the Brazilian republican period, the city of Belo Horizonte represents the new mentality that came up to replace the marks left by the years of the imperial domination. The occupation of the urban space occurred in a hierarchical and segregating way, representing a urban model created to control the masses. This text analyses the chronicles written by Carlos Drummond de Andrade and published by Minas Gerais newspaper from 1930 to 1934, which show how the author built his representations of the modern city.
\end{abstract}

Keywords: literature; city; modernity.

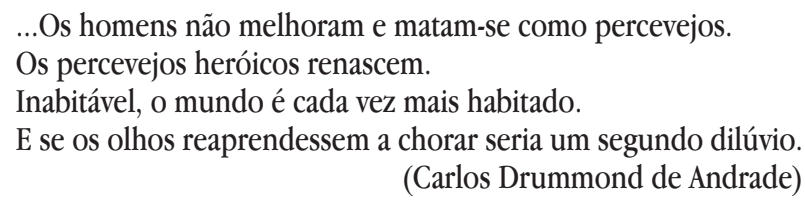

O aparecimento da cidade na história da humanidade começa no tempo mítico, com Caim. Na bíblia, o tema da cidade ocupa espaço relevante, já que o seu nascimento tem origem na arrogância do homem e no seu desejo de independência em relação a Deus. Narrada pelo texto bíblico no livro do Gênesis, a cidade vai sendo construída pelas mãos do homem: vítima da maldição de Deus por desobediência às Suas leis, Caim trabalha o barro e edifica a sua cidade, nomeando-a Henoc. Ele vê a possibilidade de determinar suas próprias leis, sem mais subordinar-se aos mandamentos e desígnios divinos. Ali, homens e mulheres iriam se estabelecer, para deixarem de ser andarilhos errantes. A cidade de Caim passa a ser, então, a "representação de uma criação do homem" (PESAVENTO, 1999, p.7).

Mas o desejo dos homens não para por aí. Ávidos por se fixarem na terra, os descendentes de Caim, emigrados do oriente, decidem construir também uma cidade e junto com ela uma torre, que ficou conhecida como Torre de Babel. A torre representava o sonho do homem em chegar mais próximo do céu para, quem sabe, receber as dádivas divinas e se assemelhar ao espírito dos deuses. Eles julgavam que com esse grandioso feito obteriam fama e respeito de todos os povos do mundo. Vendo a audácia de tão vultoso empreendimento e percebendo que os projetos humanos jamais teriam fim, o Senhor Deus lançou sobre os homens a sua ira, imprimindo-lhes um castigo. Descendo à terra, o Senhor disse:

Eles constituem apenas um povo e falam uma única língua. Se principiarem desta maneira, coisa nenhuma os impedirá, de futuro, de realizarem todos os seus projectos. Vamos, pois, descer e confundir de tal modo a linguagem deles que não se compreendam uns aos outros. (GÊNESIS, 11:6-7) 
Tudo passou a ser confusão e conflito. Impossibilitados de levarem adiante seu projeto, os homens abandonaram a construção da torre e se dispersaram pelo mundo, fadados a viver conflituosamente. Como aponta Sandra Pesavento (1999, p.7), podemos abstrair da construção da Torre de Babel um significado que caracterizaria para sempre a vida na cidade: a "conotação do social". Se os homens não podiam mais se entender em sua "obra coletiva" diante do castigo imposto por Deus, a cidade estaria fadada a ser "centro de conflito".

Ainda que a cidade bíblica esteja configurada no plano mítico, imaginário, observamos que no plano do real e pela história da evolução da cidade, o homem não abriu mão do desejo de construir seu espaço. Ao longo do tempo, as cidades foram sendo edificadas, assumindo características diversas de acordo com cada época e passando por drásticas mudanças decorrentes da atuação e da intervenção do próprio homem.

$\mathrm{Na}$ Grécia Antiga surge o conceito de pólis, a cidade-Estado autônoma e soberana, que funcionava como uma comunidade organizada, composta de homens civilizados - ditos livres e iguais - aos quais era destinado o exercício das práticas políticas. No que se refere ao espaço físico, a pólis grega se fixava em volta da acrópole e possuía um espaço central público denominado ágora, além de um mercado onde se davam as trocas comerciais. Apesar da existência de outros "organismos políticos menores" como o "ghenos, a fatria e a tribo" (WALTY e CURY, 2008), é na pólis, tida como centro, que se davam as manifestações públicas e as discussões e intervenções políticas, ações que visavam ao bem-comum e aos interesses da coletividade.

Mais tarde, na Idade Média, assistimos a uma profunda transformação da cidade com o desenvolvimento do feudalismo. A cidade sofreu mudanças, inclusive físicas, com o surgimento do "château-fort" - castelo fortificado - que era cercado por grandes muralhas, passando a ser o centro do poder. As relações políticas e sociais também foram profundamente transformadas. O poder ficou concentrado nas mãos de bem poucos - os nobres e senhores - enquanto a grande maioria dos homens era explorada, devendo submeter-se ao poderio daqueles.

Nesse período, observou-se o início da formação do entorno da cidade com a constituição dos burgos. Conforme aponta Jacques Le Goff (2004) $)^{1}$, "o burgo nasceu pela vontade de um senhor que adota um 'novo estilo' de governar - uma espécie de outsider do feudalismo -, desejoso de atrair para um determinado lugar uma população 'renovada' - formada por artesãos e comerciantes -, mas que atendesse a seus próprios interesses". Ainda segundo o autor, mais tarde as muralhas da cidade se abriram para incorporar os burgos, e o poder, antes concentrado na cidade feudal, acabou sendo dividido entre essas duas instâncias.

Entre os séculos XII e XVIII, a cidade foi palco de mais uma grande reviravolta, deixando de se constituir apenas em centro de consumo para se transformar, também, em centro de produção. Entra em cena o moinho, máquina que irá movimentar as produções de vinho, a moagem de grãos e a preparação de lã nas cidades. É nesse período que surge uma nova categoria social: a burguesia. Objetivando o fortalecimento

1 Entrevista concedida por Jacques Le Goff e publicada originalmente na revista Le Point, $\mathrm{n}^{\circ}$ duplo 1684/1685, de 23 a 30 de dezembro de 2004. Republicada na Revista Eletrônica VIVERCIDADES em 08/04/05, sob o título "As cidades medievais estão na gênese do Estado moderno", versão utilizada para consulta deste trabalho. 
do comércio e a derrubada dos privilégios do feudalismo, os burgueses - homens que viviam e trabalhavam nos burgos - deram início à formação de associações de artesãos e comerciantes, as chamadas guildas, que tinham leis e regras próprias de funcionamento, o que lhes conferia prerrogativas para atuar econômica e politicamente, visando à liberdade e à igualdade entre os homens.

Com o advento da modernidade, consolidado pela Revolução Industrial e o desenvolvimento do capitalismo, assistimos ao início de drásticas mudanças operadas na estrutura da cidade e que trouxeram impactos tanto no espaço, quanto nas relações econômicas, sociais e culturais. Os processos de industrialização e urbanização aumentaram significativamente a produção de bens e serviços, fazendo com que a cidade se tornasse o centro, por excelência, da circulação de mercadorias. A população da cidade cresceu, em termos quantitativos, em decorrência da migração de pessoas que viviam no campo, passando a reunir não só muitas pessoas, mas tipos sociais diferentes. No plano espacial, experimentou um processo de reordenamento e racionalização: a singularidade e a irregularidade originais das pequenas cidades foram substituídas por ruas e avenidas geometricamente planejadas, atingindo, consequentemente, as antigas moradias. A modernidade surgiu sob o signo da mudança e o progresso passou a ser a ideia básica que deu movimento a tudo. O ritmo veloz imposto à produção pela revolução industrial foi o mesmo ritmo que a modernidade impôs à sociedade. Tudo era novo e a novidade se tornou uma forma de seduzir o homem, mostrando que foi mesmo na cidade que o "espírito moderno" encontrou as condições ideais para se desenvolver. A racionalização do espaço e também das próprias relações sociais, que se viram profundamente modificadas em razão da objetividade das relações econômicas, produziram no homem urbano um sentimento de ambiguidade entre o choque causado pelo novo e a ruptura com as referências da tradição, talvez uma das consequências mais marcantes da modernidade. As relações impessoais, o relativo anonimato do homem no meio urbano e a experiência pela qual passou para assimilar rapidamente tudo que era estranho constituíram-se elementos de tensão que marcaram a vida nos centros urbanos. É justamente essa tensão que possibilita um estudo multidisciplinar do tema nas diversas áreas do conhecimento como a sociologia, a antropologia, a psicanálise e a literatura, na tentativa de suscitar uma reflexão sobre os modos como o homem se relacionou com esse seu espaço, de onde se pode sempre construir novos significados pelas fendas ocasionadas na passagem da tradição para a modernidade.

Em A Aventura Semiológica, Barthes diz que "a cidade é um discurso, e esse discurso é verdadeiramente uma linguagem: a cidade fala aos seus habitantes, nós falamos a nossa cidade..." (1987, p.184). Lucrecia D’Alessio Ferrara (1993, p.201) também pontua que "por sobre as causas e consequências do fenômeno urbano" estão "as imagens da cidade: ruas, avenidas, praças, galerias", apontando para o fato de que a cidade se dá a ler nessas imagens e signos que a constituem, podendo ser transfigurada e reconstruída numa diversidade de significações.

Nesse sentido, a literatura, pela capacidade de promover o deslocamento de elementos para a construção de novos significados, opera como uma leitura que confere "um sentido e uma função" (PESAVENTO, 1999) aos cenários da cidade, ordenando o real e lhe dando um valor. Evidentemente, há que se considerar que o modo como essas imagens serão representadas dependerá dos filtros de percepção de quem realiza essa leitura, como aponta Sandra Pesavento quando diz que "a atribuição de sentido às ima- 
gens poderá depender do ponto de vista ou do lugar de quem vê e de como sente aquilo que se apresenta”. (1999, p.17). Isso significa dizer que um determinado discurso, que fale sobre a cidade, de forma alguma esgota a realidade dada, mas apenas manifesta aspectos de situações que foram experimentadas ou oferecidas para apreciação. Pelo fato de representar impressões específicas acerca da realidade, esse discurso será sempre atravessado por subjetividades e intenções que se colocam ali, no texto, suscitando infinitas possibilidades de compreensão.

Na literatura brasileira, a cidade moderna também foi objeto de muitas e contraditórias representações e os escritores que se debruçaram sobre o tema marcaram, em suas obras, diferentes percepções e impressões acerca das mudanças trazidas pela modernidade. Com Belo Horizonte não foi diferente. Inaugurada em 1897, símbolo da primeira grande obra da República brasileira, a cidade nasce como o marco de uma nova mentalidade que veio para limpar os rastros do passado e sepultar as marcas deixadas por três séculos de dominação do Império. Entretanto, como toda mudança tem seu preço, o desejo de verem concretizadas, de modo rápido, as obras que representassem o moderno fez com que o projeto da capital mineira tirasse de cena histórias, lugares e pessoas. Traços de um projeto elitista e positivista que, em nome da modernidade, primou pelo planejamento racional e pela higienização dos espaços, confirmando o que aponta Sandra J. Pesavento (1999, p.16), quando diz que toda mudança realizada no espaço da cidade não deixa de conter em si um projeto de cunho político. Nota-se que para tornar possível a construção da área central, os idealizadores privilegiaram o equilíbrio e a higienização em nome da ordem e do controle, impedindo que a população mais pobre tivesse acesso a essa região nobre da cidade, já que sua ocupação estava limitada à população de maior poder econômico (Cf. ANDRADE, 2004).

$O$ antigo Curral D'el Rei cedeu lugar a uma cidade geometricamente planejada e ao traçado urbanístico inspirado nos modelos europeus e americanos do século $\mathrm{XIX}$, constituindo-se em terreno fértil para que os jovens escritores do início da década de 20 iniciassem a produção de seus primeiros textos literários sobre o fenômeno urbano na capital mineira. Abgar Renault, João Alphonsus, Pedro Nava, Milton Campos, Ciro dos Anjos, Alberto Campos e Carlos Drummond de Andrade estão entre os que se destacaram nas páginas do jornal Diário de Minas, com publicações que traziam os primeiros sinais da modernidade em Belo Horizonte.

Carlos Drummond de Andrade deixou a cidade itabirana ainda muito jovem, vindo para Belo Horizonte onde ingressou cedo no meio intelectual, jornalístico e literário da cidade. Trabalhou durante alguns anos no Diário de Minas, onde chegou a publicar algumas crônicas, tendo iniciado, em 1926, sua carreira de funcionário público no Minas Gerais - órgão oficial do Estado - ocupando, depois, o cargo de redator-chefe. Passou por uma vasta experiência de vida no centro urbano, o que marcaria significativamente a sua obra literária ao eleger a cidade como um de seus principais temas. Por ter tido uma vasta experiência urbana na capital mineira, Belo Horizonte foi tema recorrente na obra de Drummond, marcando seus textos em prosa e também sua poesia, através dos quais o escritor construiu suas representações da cidade moderna. Neste trabalho serão analisadas apenas algumas das crônicas escritas entre os anos de 1930-1934.

Publicadas no Minas Gerais sob o título de "Notas Sociais", as crônicas se resumiam em breves relatos, porém registrando ricas observações sobre o cotidiano de Belo Horizonte. Iam assinadas por pseudônimos - Barba Azul e Antônio Crispim - e 
tematizavam a moda, as exposições, as viagens de bonde, os bailes, a arquitetura e o traçado da cidade. Apesar de, à primeira vista, parecerem tratar de assuntos banais e sem importância, na verdade representavam, mesmo que ambiguamente, uma crítica do autor à frivolidade da vida moderna, assim como uma reflexão acerca de valores que vinham sendo perdidos diante da fugacidade do moderno. Na crônica que abre a série assinada pelo pseudônimo de Barba Azul, é anunciada a proposta dos assuntos que seriam tratados, relacionados a eventos passageiros da vida moderna para, na verdade, mostrar sua efemeridade:

Nesta seção se falará de moda, de sentimentos que passam com ela, de atrizes bonitas de cinema, de poetas que não usam entorpecentes nem os fabricam, e de mil outros assuntos terrestres. A senha será: Frivolidade, que, às vezes se confunde com Espírito, outras vezes (sem parecer) é mais grave que um tratado de Finanças... A seção será curta, como a vida, mas sem as complicações da vida, como o telefone não-automático, o calo pisado na rua, o amor pisado no coração... sairá todo dia útil (domingo) e até mesmo nos dias inúteis (os outros dias)... Também não há programa. A preocupação única é: aborrecer pouco, aborrecer o menos possível. (ANDRADE, 1984, p.146) ${ }^{2}$

As crônicas também revelam a forma como o autor critica o projeto de idealização da cidade que evidenciava o objetivo político dos planejadores. As construções do antigo Curral D'el Rei tiveram que ser demolidas por não coincidirem com o cenário projetado para a nova capital, que previa a divisão da cidade em três áreas: central, suburbana e rural. Desde a planta, entrevia-se os ideais de higienização que primavam pelo planejamento racional dos espaços para fazer de Belo Horizonte uma cidade controlada e "limpa". A ocupação do espaço urbano se deu de forma hirearquizada e segregativa, deixando a população mais pobre de fora do traçado da área central. Tratava-se de um modelo urbano que exercia o controle sobre as massas. Na crônica "Amigos do Verde", o cronista, num tom irônico, critica a poda das árvores da Avenida Afonso Pena. Notese que "podar" significa tirar os excessos, limpar. Com a poda das árvores, a avenida ficaria mais visível, facilitando o controle da população que teria acesso ao centro da cidade. Sutilmente, o cronista ainda aponta que a poda não foi realizada em locais mais periféricos ao centro, para os quais não havia a preocupação com a limpeza ou com o controle:

Amigos do verde, porque lamentais a perda de folhagem verificada em uma artéria da cidade, quando há tanto verde por aí, nesses campos afora, e tão mal aproveitado?... Deixem a Prefeitura realizar, com sossego, a poda indispensável. (grifo meu, ANDRADE, 1984, p.78)

Em outra crônica, "A Avenida ao Sol", o exercício desse controle também é entrevisto: “...O túnel espesso de verdura de antigamente cedera lugar a um desenho

2 Todas as citações das crônicas de Carlos Drummond de Andrade foram retiradas do livro Crônicas - 1930-1934, fruto de pesquisa realizada pelo Arquivo Público Mineiro e publicado em 1984 pela Secretaria de Estado da Cultura de Minas Gerais e serão, a partir de agora, indicadas apenas pelo número da página. 
menos compacto e vegetalmente mais policiado..." (grifo meu, p.76).

As drásticas mudanças trazidas pela modernidade fizeram aflorar, nos escritores que presenciaram a rapidez dos acontecimentos modernos, um sentimento de perda da tradição. Nas crônicas de Drummond, a mesma voz que criticava e denunciava as consequências da vida moderna, lamentava o que estava sendo perdido em nome da nova ordem. Na crônica "Da Velha Cidade", Drummond revive a Belo Horizonte de poucas décadas atrás, ainda pequena e limitada em seu espaço e onde a vida era mais pacata e tranquila:

Em uma velha cidade... Senti-me outra vez na Belo Horizonte de 1915, 1920, idades mitológicas, de que não há memória entre os homens e as mulheres de hoje... $\mathrm{O}$ mundo era pequeno e limitava-se ao norte pelo Café Estrela, na rua da Bahia, e a leste pela casa Oscar Marques, na Avenida Afonso Pena. Podia-se correr o Parque Municipal sobre essa coisa ingênua e primitiva, uma bicicleta. E os sorvetes daquele tempo?... (p. 124)

Mesmo tendo sido considerada a sede da modernidade, Belo Horizonte ainda mantinha as características de uma cidade pacata, calma e tranquila, que para Drummond muitas vezes representavam, paradoxalmente, sinônimo de tédio. Como as atividades de diversão e lazer eram raras por conta do próprio inacabamento das construções após a inauguração, a cidade se configurava pouco diversificada aos olhos do cronista, se comparada a outras como Rio de Janeiro e São Paulo. Atitude paradoxal, que ao mesmo tempo em que lamenta a perda da antiga cidade, critica seu lento processo de modernização. Em "Luzes da Cidade", o cronista fala do "atraso" da capital mineira em relação ao Rio de Janeiro e, em "Golfinho e outros substantivos", ironiza o lento acesso às novidades da moda e de produtos vindos de outros cantos do mundo:

As vitrinas apagaram-se na noite de Belo Horizonte. Atrás dos vidros, na hora em que o burguês faz a sua digestão ambulante e as meninas saem do cinema, já não há mais nada para espiar... Enquanto isso, os jornais do Rio anunciam ironicamente os concursos de vitrinas. Nós aqui podíamos fazer o mesmo: indagar qual a vitrina mais escura e, como prêmio, oferecer ao proprietário um lampião a gasolina. (Luzes da Cidade, p.200)

As elegantes cariocas estreiam modelos notabilíssimos de manteaus russos, siberianos e poloneses, que só chegarão ao conhecimento da família mineira (se chegarem) em dezembro de 1931, isto é, quando toda gente estiver tomando sorvete de coco no bar do Automóvel Club. (Golfinho e outros substantivos, p.148)

Belo Horizonte aparece, pois, nas crônicas também como a cidade do tédio o que, segundo Drummond, devia-se em grande parte ao conservadorismo dos mineiros. Em "Os dedos sobre o teclado", o cronista aponta a frieza e a falta de graça do belohorizontino quando recebe na cidade a visita de uma famosa pianista: “...Essas velhas palmas belo-horizontinas, palmas chochas e insossas, que desde os tempos de Curral del-Rei caracterizam a clássica pobreza mineira de entusiasmo..." (p.114). Na crônica "Do frio que chegou", o cronista parece apontar para o tédio até mesmo em relação à 
paisagem, que se tornava monótona como se a cidade só vivesse em uma estação do ano. Na verdade, percebe-se que esse apontamento revela uma ironia em relação à modernidade: a paisagem natural da cidade não combina com a nova arquitetura; a permanência da paisagem, sempre a mesma, contrapõe-se às imagens modernas, sempre passageiras e em constante mudança. $O$ verde das árvores e o azul da colina, elementos que conduzem a uma subjetividade, entram em contradição com a objetividade e a racionalidade do moderno:

Porque Belo Horizonte, com todo esse verde, com todo esse azul que enche as suas ruas e vai até indiscrição de penetrar nas suas casas, dá a muita gente a impressão de um paraíso monotonamente primaveril. É verde demais. Azul demais. Assim, só em verso, e o verso não é a substância de que se faz o nosso dia-a-dia terreno. (p.10)

Paradoxalmente, ao mesmo tempo em que critica o lento processo de modernização de Belo Horizonte, Drummond critica a própria modernidade, apontando seus aspectos negativos. O deslumbramento diante do novo versus o estranhamento diante das rápidas mudanças e a recusa ao progresso pelo apego à tradição traduz o sentimento dual de admiração e repulsa pelo moderno, falado por Walter Benjamin ao analisar a obra de Baudelaire. Nas crônicas "A Música da Cidade" e "Domingo de Ramos", esboça-se um lamento quanto à perda de costumes tradicionais da cultura mineira e de antigos rituais que alimentavam as crenças religiosas:

As posturas municipais, sacrificando o pitoresco em benefício da segurança pública, proibiram o Judas, como proibiram os balões coloridos da noite de São João. Belo Horizonte hoje é uma capital como as outras, com as suas noites de junho e os seus sábados de aleluia desprovidos dessa matéria-prima de poesia, demasiado explosiva talvez, mas por isso mesmo mais humana, porque há sempre uma porção de dinamite esperando estourar, dentro de nossa pobre alma urbana e civilizada. (Música da Cidade, p.50)

Deve ser da minha meninice, que ficou para trás dos alcantis da Serra do Curral, num canto de terra em que o trem não chega. Deve ser desse tempo em que a imagem das coisas, tão deformada como a de hoje, era entretanto bem diversa da de hoje, porque os olhos do garoto guardavam um lume de curiosidade que já não se acende nos olhos do homem feito. Sim, deve ser de bem longe essa impressão que eu guardo da Semana Santa.. (Domingo de Ramos, p.46)

Assim, ainda que tenha demonstrado admiração pelo novo, Drummond não se entrega totalmente "ao prazer do espetáculo moderno" (BENJAMIN, 1994), mantendo sempre uma consciência crítica em relação à modernidade. Em "Perigos da Casa Modernista", critica o excesso de exposição das coisas e objetos que, com sua beleza e imponência, causam fascínio no espectador. Há uma preocupação do cronista em apontar para a efemeridade das obras e objetos modernos, alertando para o perigo de se deixar enganar por eles e não se aperceber do que está escondido por trás de sua aparência: 
A época é de exposições, de quadros, de vestidos, de automóveis, de porcelanas, de cães, de fenômenos naturais e artificiais... Afinal, tudo é exposição, ou dá ensejo a ela... A casa modernista, alegre e insolente, lá está exposta, e dizem os jornais que com enorme sucesso. Não consigo imaginar é o que, terminando esse sucesso enorme, irão fazer de seus alicerces. Sim, porque provavelmente só os alicerces resistirão à voracidade dos visitantes. (p.20)

Em "A Casa Habitável", observa-se uma crítica à impessoalidade das casas modernas, construídas com estruturas de ferro e vidro - símbolos da modernidade - apontando para a necessidade de se valorizar a casa como lugar de intimidade do homem e sua família, atributo perdido pela exposição a que são colocadas as pessoas, as coisas e os lugares. Nota-se que a privacidade do homem vai sendo também colocada à mostra, o que nos leva a refletir sobre a inversão dos espaços na vida moderna, em que o privado passa a ter predomínio sobre o público:

Penso nessa casa de vidro que o arquiteto Pierre Chareau acaba de construir em Paris. É uma casa para família, e todas as paredes, portas, mármores, metais e boiseries são de vidro autêntico, inquebrável e translúcido. O telegrama não diz, mas está se vendo que para uma casa assim de vidro, só uma família de vidro... Porque até agora a casa não era só o lugar do repouso e do café matinal, em chinelas, com a alegria dos filhos promovendo desordens no alpendre. Era também, e principalmente, o lugar onde o indivíduo se abrigava do mundo... Agora, surge-nos o sr. Pierre Chareau e instala, numa casa de vidro, um homem sem mistério e sem intimidade... (p.130)

A ambiguidade também se marca nas crônicas quando é revelado o contraste entre o provincianismo e os hábitos modernos. A crônica "Vamos ver a cidade" mostra a aparente sedução pelo novo, sem esconder o apego ao tradicional. Misturando-se às luzes e à geometria da cidade, as antigas cadeiras de palhinha contrapóem-se às imagens modernas: 0 asfalto, as vitrines e a moda:

Da Serra até a antiga Praça do Mercado, duas fieiras de luzes compõem uma "feerie" geométrica. A cidade acabou de jantar... $\mathrm{Na}$ rua Piauí há cadeiras de palhinha pelas calçadas... Enquanto isso, as moças fazem o footing na Avenida Paraúna, cujo asfalto brilha como um sapato novo... As vitrines expõem o último modelo de sweater e a aquarela da senhorita X... (p.96)

O mesmo olhar que se embevece diante do novo, também registra o injusto contraste entre os privilégios concedidos para o centro da cidade e as desvalias que marcam sua periferia: "A cidade ficou lá adiante, com seus ruídos e fogos. Nesses morros, os bairros modestos se alastram laboriosamente, reclamando água, luz, bondes, telefones e lojas de sírios..." (grifos meus, p.96).

Apesar de parecer que o recorte operado nas crônicas recai sobre a área central de Belo Horizonte, o olhar crítico e atento de Drummond não deixa escapar a realidade das regiões periféricas, no intuito de mostrar o enorme contraste dos espaços geográficos, econômicos e sociais, como se observa na crônica "KODAK". É interessante 
notar, nesse texto, que o cronista se vale da simbologia da máquina fotográfica parecendo querer fixar cenas e espaços, consciente que está da efemeridade da vida moderna e da fugacidade dos acontecimentos. É como se sua intenção fosse a de congelar aquelas imagens, naqueles momentos, para torná-las duradouras antes de serem substituídas por outras. Ressalte-se, ainda, o modo fragmentado como a cidade é percebida mostrando que, por demasiado complexa, acaba revelando a impossibilidade de se abarcar toda sua diversidade. A crônica é, assim, composta de fragmentos; instantâneos de imagens da vida citadina que representam algum valor crítico ou reflexivo aos olhos de Drummond. São fragmentos de sete espaços diferentes da cidade, privilegiando aspectos peculiares a cada um, como se a cidade fosse mesmo um mosaico; um espaço que se constrói pela diversidade de valores, profissões, etnias, costumes e vivências:

Eu conheci a rua da Bahia quando ela era feliz. Era feliz e tinha um ar de importância que irritava as outras ruas da cidade.

Um dia, parece que a rua da Bahia teve um desgosto qualquer e começou a decair. Hoje, a gente olha para ela com um respeito meio irônico e meio triste... (p.54)

Gosto da rua Caetés, a rua mais interessante da cidade. Rua de bigodes e gritos joviais, de pequeninos arranha-céus e de grandes laranjas amadurecendo em caixotes. Rua de sedas e vitrolas. Elegante. Popular. Nossa. E depois, é também a rua mais camarada de todas: sempre disposta a fazer uma diferença, para você ficar freguês... (p.54)

Eu não tenho pena dos basbaques que anoitecem no Bar do Ponto, vendo a vida e as mulheres passarem. Tenho pena é do Bar do Ponto, que suporta esses basbaques, há 33 anos. (p.54).

$\mathrm{Na}$ estrada que leva ao Barreiro, os amigos do pitoresco encontrarão a Cabana do Pai Tomás, que não é cabana e não pertence ao pai Tomás: tipo de vendinha de beira de estrada, com a "abrideira" dentro do pipote, num canto do balcão... (p.54)

O último concurso de beleza deu-nos alguma coisa que meditar. A vitória de "miss" Carlos Prates é de algum modo a vitória de Carlos Prates, do bairro desmerecido que até bem pouco a Serra e os Funcionários não ligavam... Um dia chegará a vez de "miss" Palmital, e desde já fiquem avisados de que o Palmital é a paisagem mais larga, arejada e bonita de Belo Horizonte. (p.54)

Muito tempo depois da publicação dessas crônicas, Drummond volta a olhar a cidade e ela já é completamente outra, muito diferente daquela criticada por ele como entediante e sem graça. Mais uma vez, a ambiguidade que marcou seu espírito moderno é manifestada no poema memorialista "Triste Horizonte", escrito na década de 70, quando Belo Horizonte já tinha se tornado uma grande metrópole. No poema, Drummond lamenta o progresso sem controle e deseja rever a velha cidade dos anos 30. A geometria do plano, as linhas retas, as formas do novo traçado, não conseguem esconder o contorno dos morros, os caminhos sinuosos, a irregularidade da pedra que insistem em manter seus rastros, mesmo que só apareçam nos momentos em que se (re) visita a memória: 


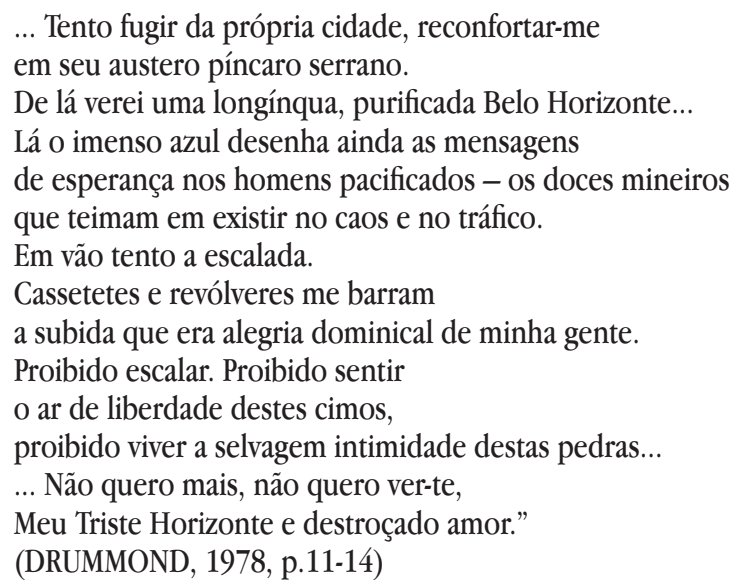

A diversidade inaugurada pela modernidade fez da cidade um lugar de contradições, paradoxos e ambiguidades percebidos não só nas imagens e signos, mas no próprio comportamento humano. No turbilhão de acontecimentos e vivências urbanas, Drummond registrou nessas crônicas o sentimento paradoxal e ambíguo do homem moderno, colocando à mostra os nítidos contrastes entre a vontade de aceitar e viver 0 novo - que se coloca fugidio, estranho, mas necessário - e o recorrente apego à estabilidade da vida tradicional. Ainda que tenha sido o marco da modernidade da República, as representações que Drummond fez de Belo Horizonte apontam para a cidade provinciana que, paradoxalmente, ele criticou nas crônicas, revelando um sentimento ambíguo.

Nem mesmo mais tarde, quando Drummond escreve seus textos memorialísticos, esse paradoxo é resolvido. A própria memória se faz paradoxal ao se contrapor ao moderno, já que ela não é efêmera e nem fugaz. Conforme Sandra Pesavento, a contraposição de elementos do passado com os do presente busca novas significações para o entendimento de uma determinada época (1999, p.23), exercício que, sem dúvida, é possibilitado pela memória. Se o cotidiano marca as crônicas da década de 30, o que marca "Triste Horizonte" é a própria memória do escritor, consciente que está de que não há como conter o crescimento e o progresso da metrópole. Nesse sentido, ele não busca a reconstrução do espaço citadino dos anos 30, mas o entendimento do que ocorreu nesse espaço, pelo exercício da consciência subjetiva.

\section{Referências bibliográficas}

ANDRADE, Carlos Drummond de. Boitempo. In: Poesia Completa. Rio de Janeiro: Nova Aguilar S.A., 2002.

. Um minuto apenas. In: Crônicas - 1930-1934, Arquivo Público Mineiro, Belo Horizonte, 1984.

. In: Crônicas - 1930-1934, Arquivo Público Mineiro, Belo Horizonte, 1984, p.78.

. A Avenida ao Sol. In: Crônicas - 1930-1934, Arquivo Público Mineiro, Belo Horizonte, 1984, p.76. 
. Da Velha Cidade In: Crônicas - 1930-1934, Arquivo Público Mineiro, Belo Horizonte, 1984, p.124. Horizonte, 1984, p.54.

Kodak. In: Crônicas - 1930-1934, Arquivo Público Mineiro, Belo . Luzes da Cidade. In: Crônicas - 1930-1934, Arquivo Público Mineiro, Belo Horizonte, 1984, p.200.

. Golfinho e Outros Substantivos. In: Crônicas - 1930-1934, Arquivo Público Mineiro, Belo Horizonte, 1984, p.148.

. Os Dedos sobre o Teclado. In: Crônicas - 1930-1934, Arquivo Público Mineiro, Belo Horizonte, 1984, p.114.

. Do Frio que Chegou. In: Crônicas - 1930-1934, Arquivo Público Mineiro, Belo Horizonte, 1984, p.10.

. A Música da Cidade. In: Crônicas - 1930-1934, Arquivo Público Mineiro, Belo Horizonte, 1984, p.50.

. Domingo de Ramos. In: Crônicas - 1930-1934, Arquivo Público Mineiro, Belo Horizonte, 1984, p.46.

. Perigos da Casa Modernista. In: Crônicas - 1930-1934, Arquivo Público Mineiro, Belo Horizonte, 1984, p.20.

Belo Horizonte, 1984, p.130.

A Casa Habitável. In: Crônicas - 1930-1934, Arquivo Público Mineiro, neiro, Belo Horizonte, 1984, p.96.

Vamos Ver a Cidade. In: Crônicas - 1930-1934, Arquivo Público Mi. Um minuto apenas. In: Crônicas - 1930-1934,Arquivo Público Mineiro, Belo Horizonte, 1984, p.146.

. Discurso de primavera e algumas sombras. 2.ed. aum. - Rio de Janeiro: J. Olympio, 1978, p.11-14.

ANDRADE, Luciana Teixeira de. As representações da cidade moderna na literatura. In: A Belo Horizonte dos Modernistas: representações ambivalentes da cidade moderna. Belo Horizonte: Editora PucMinas, 2004.

. As representações de Belo Horizonte nas obras de Cyro dos Anjos, Pedro Nava e Carlos Drummond de Andrade. In: A Belo Horizonte dos Modernistas: representações ambivalentes da cidade moderna. Belo Horizonte: Editora PucMinas, 2004.

BENJAMIN, Walter. Paris do Segundo Império. In: Charles Baudelaire: um lírico no auge do capitalismo. São Paulo: Brasiliense, 1994 (Obras Escolhidas III).

O Flâneur. In: Charles Baudelaire; um lírico no auge do capitalismo. São Paulo: Brasiliense, 1994 (Obras Escolhidas III), p.185-236.

BERMAN, Marshal. Tudo que é sólido desmancha no ar. A aventura da modernidade. Trad. Carlos Felipe Moisés e Ana Maria Ioriatti. São Paulo: Companhia das Letras, 1986.

BÍBLIA SAGRADA. Edição da Palavra Viva. Trad. Missionários Capuchinhos. Lisboa, 1974.

DE CERTEAU, Michel. Caminhadas pela cidade. In: A invenção do cotidiano. Artes de fazer. Trad. Ephraim Ferreira Alves. Rio de Janeiro: Vozes, 1994, p.169-192.

FERRARA, Lucrécia D'Alessio. Olhar periférico. Informação, linguagem, percepção ambiental. São Paulo: Edusp, 1993. 
FREITAG, Bárbara. Teorias da cidade. Campinas: Papirus, 2006.

In: HARDMAN, Francisco Foot. Chuva, vapor, velocidade: projeções à sombra do mecanismo. Trem fantasma: a modernidade na selva. São Paulo: Cia. das Letras, 1988.

PESAVENTO, Sandra J. O imaginário da cidade. Visões literárias do urbano. Porto Alegre: Editora da Universidade, 1999.

RAMA, Angel. A cidade das letras. São Paulo: Brasiliense, 1985, p. 42-75.

2008.

WALTY, Ivete e CURY, Maria Zilda. Polis e letra. (no prelo). Belo Horizonte,

Entrevista com Jacques Le Goff publicada originalmente na revista Le Point, $\mathrm{n}$. duplo 1684/1685, de dezembro de 2004 e republicada com tradução de Letícia Ligneul Cotrim na Revista Eletrônica Vivercidades. Acesso em 05/11/08.

$<$ http://www.skyscrapercity.com/showthread.php?t $=450672>$ Acesso em: 03 jul. 2008.

$<$ http://www.comciencia.br/comciencia/?section $=8 \&$ tipo $=$ entrevista\&edic $\mathrm{ao}=11>$ Acesso em: 03 jul. 2008.

< http://pt.wikipedia.org/wiki/Torre_de_Babel> Acesso em: 14 jul. 2008.

$<$ http://www.vivercidades.org.br/publique222/cgi/cgilua.exe/sys/start. htm?infoid=877\&sid=19> Acesso em: 06 nov. 2008.

$<$ www.lusitanocoelhomg2004.blogspot.com/2008/05/em-bh-na-dcadade-20.html. > Acesso em: 21 jan. 2009.

$<$ http://pt.wikipedia.org/wiki/Belo_Horizonte> Acesso em: 05 nov. 2008 